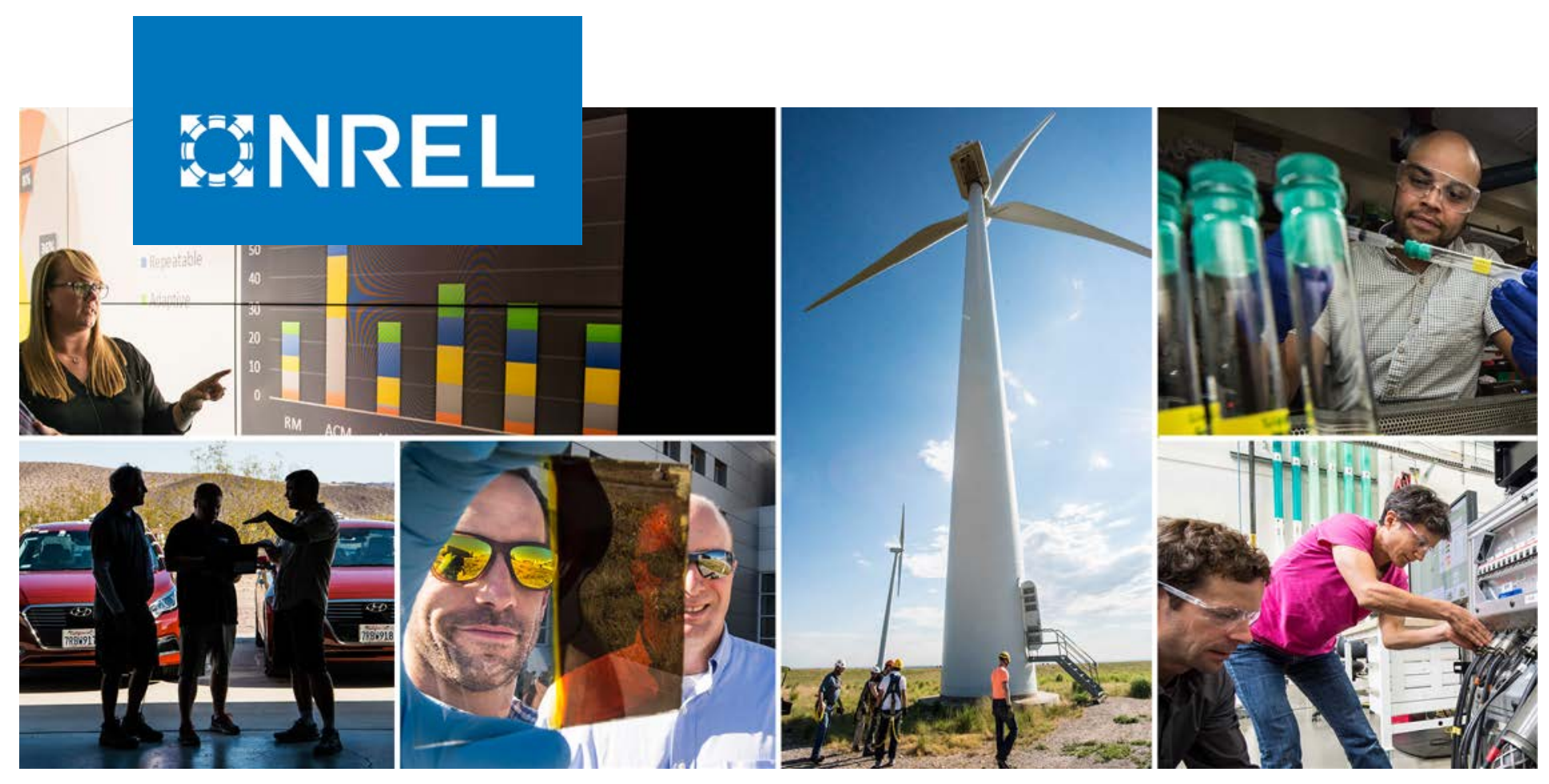

\title{
History of Ethanol Fuel Adoption in the United States: Policy, Economics, and Logistics
}

Caley Johnson, ${ }^{1}$ Kristi Moriarty, ${ }^{1}$ Teresa Alleman, ${ }^{1}$ and Danilo Santini ${ }^{2}$

1 National Renewable Energy Laboratory

2 Argonne National Laboratory

NREL is a national laboratory of the U.S. Department of Energy

Office of Energy Efficiency \& Renewable Energy

Operated by the Alliance for Sustainable Energy, LLC

This report is available at no cost from the National Renewable Energy Laboratory (NREL) at www.nrel.gov/publications.
Technical Report

NREL/TP-5400-76260

November 2021 


\title{
BNREL
}

\section{History of Ethanol Fuel Adoption in the United States: Policy, Economics, and Logistics}

\author{
Caley Johnson, ${ }^{1}$ Kristi Moriarty, ${ }^{1}$ Teresa Alleman,,${ }^{1}$ and \\ Danilo Santini²
}

1 National Renewable Energy Laboratory

2 Argonne National Laboratory

\section{Suggested Citation}

Johnson, Caley, Kristi Moriarty, Teresa Alleman, and Daniolo Santini. 2021. History of Ethanol Fuel Adoption in the United States: Policy, Economics, and Logistics. Golden, CO: National Renewable Energy Laboratory. NREL/TP-5400-76260.

https://www.nrel.gov/docs/fy22osti/76260.pdf

NREL is a national laboratory of the U.S. Department of Energy Office of Energy Efficiency \& Renewable Energy Operated by the Alliance for Sustainable Energy, LLC

This report is available at no cost from the National Renewable Energy Laboratory (NREL) at www.nrel.gov/publications.

Contract No. DE-AC36-08GO28308
Technical Report

NREL/TP-5400-76260

November 2021

National Renewable Energy Laboratory 15013 Denver West Parkway Golden, CO 80401

303-275-3000 • www.nrel.gov 


\section{NOTICE}

This work was authored in part by the National Renewable Energy Laboratory, operated by Alliance for Sustainable Energy, LLC, for the U.S. Department of Energy (DOE) under Contract No. DE-AC36-08G028308. Funding provided by the U.S. Department of Energy Office of Energy Efficiency and Renewable Energy Vehicle Technologies Office. The views expressed herein do not necessarily represent the views of the DOE or the U.S. Government.

This report is available at no cost from the National Renewable Energy Laboratory (NREL) at www.nrel.gov/publications.

U.S. Department of Energy (DOE) reports produced after 1991 and a growing number of pre-1991 documents are available free via www.OSTI.gov.

Cover Photos by Dennis Schroeder: (clockwise, left to right) NREL 51934, NREL 45897, NREL 42160, NREL 45891, NREL 48097, NREL 46526.

NREL prints on paper that contains recycled content. 


\section{Acknowledgments}

The authors would like to thank the U.S. Department of Energy's Vehicle Technologies Office, Technology Integration Program for funding this project and providing connections with fuel suppliers and officials that led to key data and insight. We would also like to thank our colleagues Gina Fioroni and Cameron Hays for their input. Finally, the industry insight shared by Kristy Moore of KMoore Consulting proved invaluable.

\section{List of Acronyms}

$\begin{array}{ll}\text { AKI } & \text { anti-knock index } \\ \text { CAA } & \text { Clean Air Act } \\ \text { CAFE } & \text { Corporate Average Fuel Economy } \\ \text { DOE } & \text { U.S. Department of Energy } \\ \text { E0 } & \text { pure gasoline (0\% ethanol) } \\ \text { E10 } & 10 \% \text { ethanol fuel } \\ \text { E15 } & 10.5 \%-15 \% \text { ethanol fuel } \\ \text { E85 } & 51 \%-83 \% \text { ethanol fuel } \\ \text { EPA } & \text { U.S. Environmental Protection Agency } \\ \text { FFV } & \text { flexible-fuel vehicle } \\ \text { GGE } & \text { gasoline gallon equivalent } \\ \text { GHG } & \text { greenhouse gas } \\ \text { LDV } & \text { light-duty vehicle } \\ \text { MTBE } & \text { methyl tert-butyl ether } \\ \text { NHTSA } & \text { National Highway Transportation Safety Administration } \\ \text { NOx } & \text { nitrogen oxides } \\ \text { OEM } & \text { original equipment manufacturer } \\ \text { OPEC } & \text { Organization of the Petroleum Exporting Countries } \\ \text { RFS } & \text { Renewable Fuel Standard } \\ \text { RVP } & \text { Reid vapor pressure } \\ \text { TEL } & \text { tetra-ethyl lead } \\ \text { UL } & \text { UL LLC (formerly Underwriters Laboratories) } \\ \end{array}$




\section{Executive Summary}

Ethanol has achieved the greatest market share of all the alternative transportation fuels that have been researched, developed, and deployed in the United States. There are multiple lessons to be learned from the history of ethanol adoption that can be applied to future fuels and products.

Ethanol has replaced portions of gasoline in three main blend levels, with corresponding vehicles, equipment, benefits, and policies. The first is E10 (10\% ethanol fuel), which has replaced nearly all pure gasoline (E0) sold in the United States today (U.S. Energy Information Administration 2016. This was brought about through generations of policies that were motivated by multiple factors related to engine performance, energy security, health, air quality, and climate protection. Ethanol's high octane has been a consistent driver of the fuel because this enables higher-performance engines. Early policies (1973-1979) were largely motivated by the desire to reduce dependence on petroleum sourced from members of the Organization of the Petroleum Exporting Countries, or OPEC. Fuel policy in the 1980s was largely in pursuit of promoting octane-number enhancers that could replace lead. Criteria pollutant reduction was the overarching goal of actions taken from 1990 to 2005. From 2005 to the present, fuel policy has been largely motivated by energy security and climate protection goals. These policies were usually technology-agnostic and promoted multiple fuels and additives during each period. However, ethanol is the only fuel identified that is cost-effective, with qualities that enabled it to prosper in the policy environments of all four of these periods.

The second market for ethanol is via E85, a marketing term for a fuel containing between $51 \%$ $83 \%$ ethanol. This fuel has the advantage of a greater concentration of ethanol but the disadvantage of not being compatible with regular gasoline vehicles. Instead, it can only be used in flexible-fuel vehicles (FFVs), which can use every blend level from E0 to E85. Therefore, much of the effort to increase E85 consumption has been aimed at incentivizing automakers to manufacture FFVs, drivers to purchase FFVs, and fueling stations to equip themselves to sell E85.

The third and newest market through which ethanol is consumed is $15 \%$ ethanol (E15), which builds upon the E10 market to increase ethanol consumption by common gasoline vehicles. Efforts to create the E15 market consisted largely of testing vehicles and refueling equipment for compatibility, creating waivers to allow the use of E15, placing requirements on E15 retailers, and incentivizing retailers to equip themselves to purchase E15. 


\section{Table of Contents}

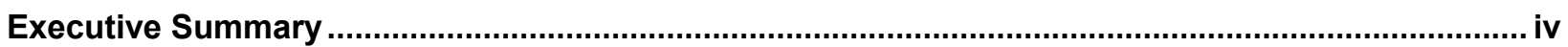

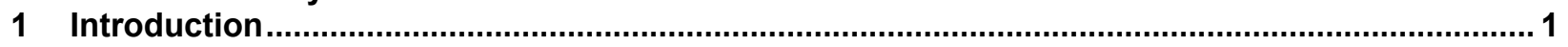

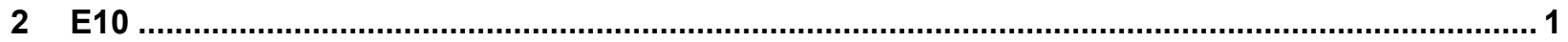

2.1 1973-1980: Energy Security Motivates the Use of Ethanol .................................................. 1

2.2 1980-1990: Lead Removal Necessitates the Use of Octane Enhancers ..................................... 2

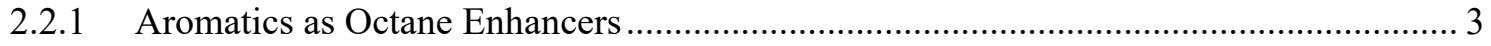

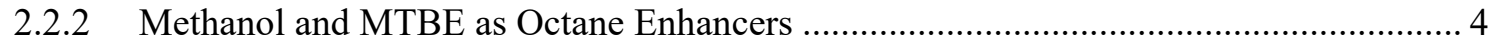

2.2.3 Use of Ethanol as an Octane Enhancer .................................................................... 5

2.3 1990-2005: Air Quality Motivates the Use of Oxygenates .................................................. 6

2.4 2005-2016: Energy Security and Climate Protection Motivate the Use of Ethanol................... 8

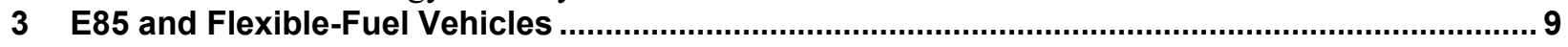

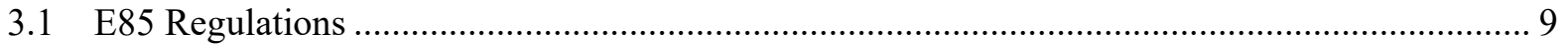

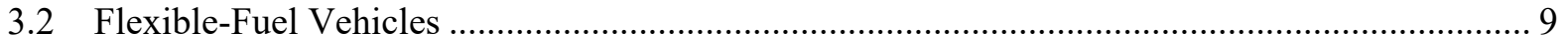

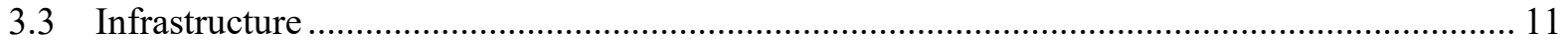

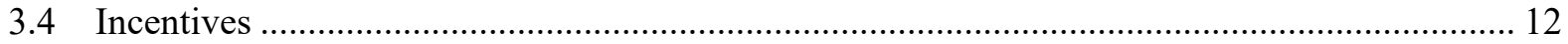

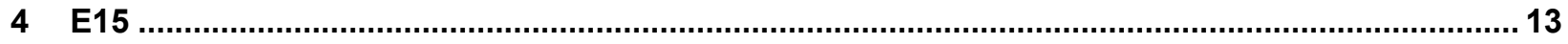

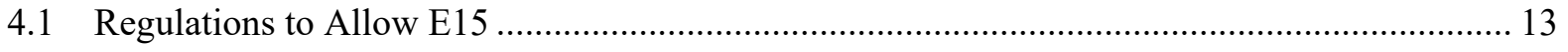

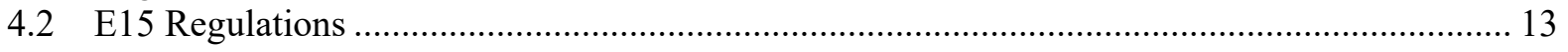

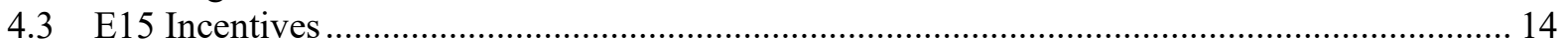

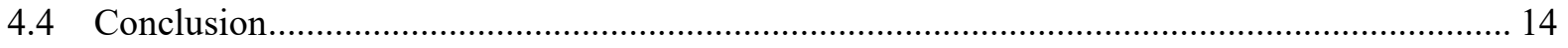

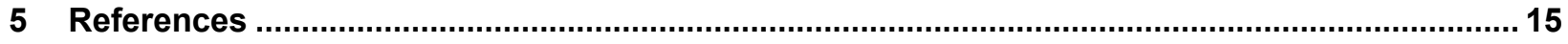




\section{List of Figures}

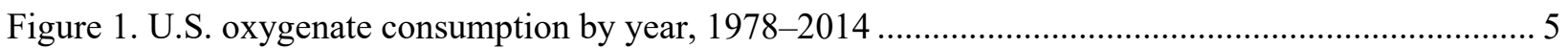

Figure 2. RFS2 legislated biofuel volumes by year ....................................................................... 8

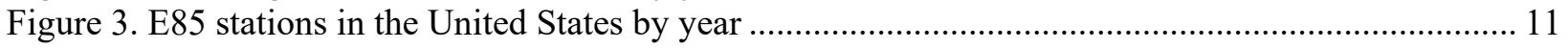

Figure 4. Yellow gas-tank cap of an FFV and matching dispenser nozzle ............................................. 12

\section{List of Tables}

Table 1. Octane Enhancers, Fuels, and Their 1991 Gulf Coast Prices ...................................................... 3 


\section{Introduction}

Of all the alternative transportation fuels that have been researched, developed, and deployed in the United States, ethanol has achieved the greatest market share. There are multiple lessons to be learned from the history of ethanol adoption that can be applied to future fuels and products. This report documents the roughly 50 years it took for ethanol to achieve the market share it sees today.

The quantities of ethanol consumed today are utilized in three fuel markets. The largest one is the E10 (10\% ethanol fuel) market. The motivations and strategies for inserting ethanol into gasoline have varied over time but have resulted in a near-complete replacement of pure gasoline (E0) with E10. Overlapping with much of the E10 market development was a push to create an E85 (85\% ethanol fuel) market, with flexible-fuel vehicles that could use gasoline, E85, or any blend in between. Finally, progress has been made to increase the blend level from E10 to E15 $(10.5 \%-15 \%$ ethanol fuel) in a relatively recent effort to replace gasoline with ethanol.

\section{$2 \mathrm{E} 10$}

Blending ethanol into nearly all gasoline at $10 \%$ levels is by far the largest market for ethanol to date, and now nearly all gasoline sold in the United States contains $10 \%$ ethanol (referred to as E10) (U.S. Energy Information Administration 2016). This was brought about through generations of policies motivated by multiple factors related to energy security, health, air quality, and climate protection. Furthermore, ethanol's high octane enables higher-performance engines because it allows them to increase their compression ratio, and therefore torque. The initial demand for an octane booster was set in place by the removal of tetra-ethyl lead (TEL) from gasoline. Early policies (1973-1979) were largely motivated by the desire to reduce dependence on petroleum sourced from members of the Organization of the Petroleum Exporting Countries, or OPEC. Fuel policy in the 1980s was largely in pursuit of promoting octane-number enhancers that could replace lead. Criteria pollutant reduction was the overarching goal of actions taken from 1990 to 2005 . From 2005 to the present, fuel policy has been largely motivated by energy security and climate protection goals. These policies were usually technology-agnostic and promoted multiple fuels and additives during each period. However, ethanol is the only fuel identified that is cost-effective, with qualities that enabled it to prosper in the policy environments of all four of these periods.

\subsection{3-1980: Energy Security Motivates the Use of Ethanol}

In the 1970s, as U.S. domestic crude oil production began to decline, prices rose and imports sharply increased. Corn processors and corn farmers saw an opportunity to market ethanol as a gasoline additive that would expand the domestically produced supply of gasoline and buoy low corn prices. Nebraska may also have seen the potential for octane enhancement as early as GM's 1970 announcement of plans to prepare for an unleaded gasoline future, as Nebraska set up an “Agricultural Products Industrial Utilization Committee" in 1971 (Round 1973).

The OPEC oil embargo of 1973-1974 galvanized this new ethanol/agriculture political clout to push for increased use of ethanol as a means to reduce U.S. dependence on foreign oil. In 1975, in another example of a state/regional initiative driving national fuel outcomes, Nebraska began conducting field tests of 10\% ethanol blends in three dozen vehicles (Bechtold 1987). Financial 
incentives, mostly tax related, soon emerged in states in the Midwest and at the federal level in the 1978-1981 period. From about 1975 to 1981, when oil prices jumped and domestic oil output dropped, the National Corn Growers Association (funded indirectly by a checkoff on corn sales), the National Gasohol Lobby, and then the newly formed Renewable Fuels Association created pressure for state and federal laws and incentives favorable to ethanol. Through a bumpy path of changing laws, incentives, regulations, and scientific and engineering analyses of merit, ethanol "stuck" in the marketplace.

Congress boosted the ethanol market in 1978 by exempting E10 (including the gasoline portion) from the federal excise tax on motor fuels (Energy Tax Act 1978). Twenty-five states followed suit and exempted E10 from all or part of their state gasoline-excise taxes. The original equipment manufacturers (OEMs) had concerns about the higher volatility of gasoline/ethanol blends creating vapor lock in the engine, but in 1979 the U.S. Environmental Protection Agency (EPA) ruled that E10 was "substantially similar" to gasoline under the Clean Air Act (CAA) 211(f) fuel authority, thereby legalizing it as a fuel (Federal Register 1979).

Fuel retailers and authorities having jurisdiction over their dispensing equipment were concerned about the effects that E10 (historically called gasohol) might have on fuel-dispensing equipment, so in 1978 Underwriters Laboratories (UL) revised their ethanol blend standard, UL 87, originally written in 1930 . This standard, allowing blends of up to $10 \%$ ethanol to be introduced without additional testing, received its first modification in 2015 (UL 87a), which dealt with blends above 10\% (Brooke Higginbotham, email message to the author, January 5, 2016). In that case, additional testing was required for higher-percentage-level blends.

The oil price spike of 1979-1981 prompted a new wave of pro-ethanol legislation. Oil companies initially resisted the renewed efforts to blend ethanol after the second oil price shock in 1979, so Congress responded with the Gasohol Competition Act of 1980, which tripled the allowable compensation that ethanol companies could receive in cases of discrimination from oil companies (Morris 1992). Congress expanded the excise tax exemption to all low-ethanol blends (important for later oxygenate requirements) and made it more flexible by allowing blenders to take it as an income tax credit (Crude Oil Windfall Profits Tax 1980). Furthermore, the Energy Security Act of 1980 provided over $\$ 1$ billion, through various mechanisms, for the construction of ethanol production facilities. At the same time, the Archer Daniels Midland Company negotiated a lower rate to transport ethanol as a fuel (instead of a chemical) by rail, barge, and truck. As a result of these policies and negotiations throughout the 1980s, substantial amounts of ethanol were splash-blended into gasoline, largely in the Corn Belt. However, there was a problem with the economics of E10. Because no blendstocks for oxygenated blending were produced at the time, the octane number of the final fuel was higher than vehicles could utilize, and therefore the increased octane number benefits were wasted.

\subsection{0-1990: Lead Removal Necessitates the Use of Octane Enhancers}

The market for ethanol opened when TEL was removed from gasoline. Without TEL or another octane booster, engine performance (torque and power) decreases. TEL was removed from gasoline for two reasons. The first was to allow use of the catalytic converter, a technology that could dramatically reduce tailpipe emissions of carbon monoxide (CO), hydrocarbons, and 
nitrogen oxides $\left(\mathrm{NO}_{\mathrm{x}}\right)$ - important ozone precursors. TEL, if not removed, would damage or "poison" the catalyst and render the catalytic converter ineffective. The second reason for reducing TEL was steadily increasing scientific certainty that tailpipe emissions of TEL were a problem contributing to learning disabilities and behavioral problems, primarily in children (Splitter, Pawlowski, and Wagner 2016).

\subsubsection{Aromatics as Octane Enhancers}

As TEL was phased out of gasoline throughout the 1980s, refineries largely made up for the lost octane number by increasing the aromatic content of gasoline-from 22 percent by volume in 1979 to 33 percent by volume in 1990 (Morris 1992). Refiners initially chose aromatics because they were the least-expensive option to increase octane number (Table 1). Volatility is measured by Reid vapor pressure (RVP), a metric that describes how easily gasoline evaporates. Because evaporated gasoline contributes to the formation of ground-level ozone, EPA began regulating RVP in 1989 (near the end of the dramatic increase in the use of aromatics). These limitations apply to summertime gasoline (because ozone formation is temperature-dependent) and differ by state, but the general limitation is that RVP must not exceed 9 pounds per square inch (psi).

Table 1. Octane Enhancers, ${ }^{1}$ Fuels, and Their 1991 Gulf Coast Prices

\begin{tabular}{lll}
\hline \multicolumn{3}{c}{ OCTANE MARKET } \\
\hline Chemical & Actual AKI & Price (\$/gal) \\
\hline Methanol & 115 & $\$ 0.37$ \\
n-Butane & 91 & $\$ 0.37$ \\
Isobutane & 121 & $\$ 0.41$ \\
\hline Ethanol (with federal E10 tax incentive) & 110 & $\$ 0.61$ \\
\hline Toluene & 103 & $\$ 0.75$ \\
Xylene & 106 & $\$ 0.75$ \\
Methyl tert-butyl ether (MTBE) & 110 & $\$ 0.98$ \\
\hline Benzene & 101 & $\$ 1.13$ \\
Ethanol (without tax incentive) & 110 & $\$ 1.15$ \\
\hline
\end{tabular}

FUEL MARKET (prices per gasoline gallon equivalent [GGE])

\begin{tabular}{lll}
\hline Fuel & Octane (R+M)/2 & Price (\$/GGE) \\
\hline Gasoline & 87 & $\$ 0.52$ \\
Ethanol (with federal E10 tax incentive) & 110 & $\$ 0.93$ \\
Ethanol (without tax incentive) & 110 & $\$ 1.75$ \\
\hline Sources: Octane Week, January 6, 1992; U.S. Energy Information Administration (1992)
\end{tabular}

\footnotetext{
${ }^{1}$ The actual anti-knock index (AKI) and the blending AKI vary depending on the base hydrocarbon composition and may be highly nonlinear. A good discussion of nonlinear octane blending is presented in Ghosh, Hickey, and Jaffe (2006).
} 


\subsubsection{Methanol and MTBE as Octane Enhancers}

The second most common option for the refineries to regain the octane number lost from the lead phaseout was the addition of methanol. The 1980s methanol advocates and investigators included major "natural-gas-rich" fossil fuel producers that were seeking corporate survival as control of Middle Eastern supplies was taken from them by members of the newly powerful OPEC.

There were very significant efforts to do the technical and legislative legwork to introduce vehicles fueled by methanol or by a liquid fuel that was predominantly methanol. A key piece of legislation was the 1990 proposal to Congress by President George H.W. Bush to introduce methanol in 19 U.S. cities. This effort ended when gasolines blended with methyl tert-butyl ether (MTBE) and sold to the entire fleet were shown to be able to provide a similar reduction in emissions compared to slow market penetration of methanol-fueled vehicles with lower tailpipe emissions and the sparse number of methanol refueling facilities (National Research Council 1991; Bechtold, Goodman, and Timbario 2007).

Methanol was relegated to more evaluations against competing alternative fuels and was completely phased out of the market by 1986 (Peeples 1991). Existing methanol producers who had supported methanol in the 1980s now promoted MTBE-based reformulated gasoline because methanol is an input in the production of MTBE. Natural gas is the primary feedstock for methanol. Thus, natural-gas-rich fossil fuel energy companies indirectly achieved their goal of use of natural gas as the basis of a liquid fuel for existing engines.

At this point, MTBE became the octane enhancer of choice. Oil companies preferred MTBE over ethanol largely because it can be produced out of a combination of refinery byproducts and methanol, processed within the refinery complex, and put in a pipeline, thus being under the control of the refiner. In addition, MTBE used existing infrastructure. The use of MTBE increased rapidly between 1985 and 1999 (see Figure 1) as part of an emphasis on premium gasoline, particularly in the summer (Colucci 2013). 


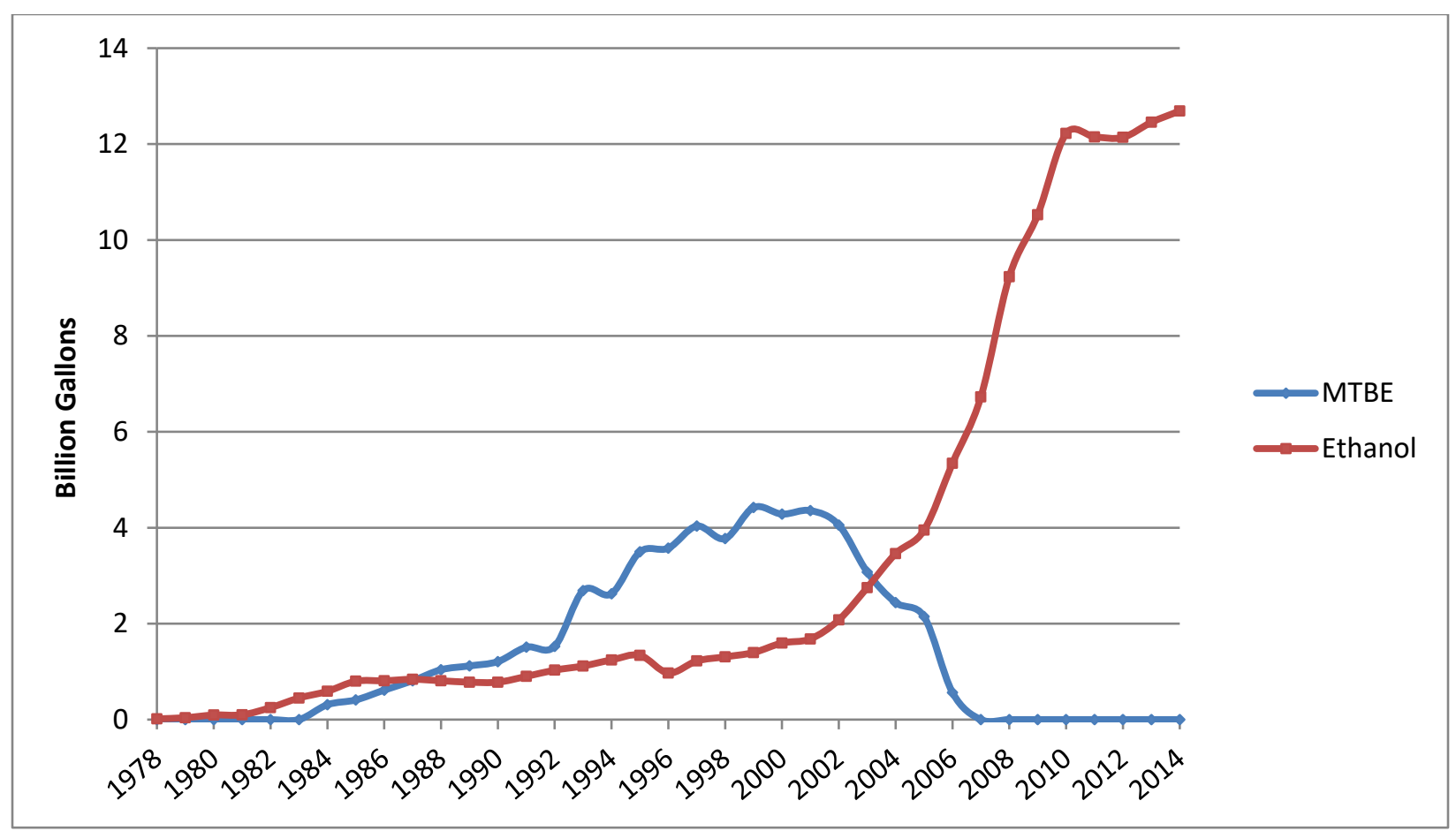

Figure 1. U.S. oxygenate consumption by year, 1978-2014

Source: 1978-1991 data: Morris (1992); 1992-2014 data: EIA Annual Energy Outlooks

\subsubsection{Use of Ethanol as an Octane Enhancer}

Ethanol was a third way to recoup the octane lost by the removal of TEL. In June 1985, Amoco, alone among oil industry majors, produced a low-octane leaded gasoline blendstock for seven Midwestern states to be used specifically with ethanol as an octane enhancer (Bechtold 1987). Presumably, the influence of an oil major was significant, leading the Williams pipeline to add a sub-octane ( 85 octane) leaded gasoline grade at eight terminals in the Midwest in July 1985, and then make its shipment available "as a regular product" in October of that year. This use finally took advantage of ethanol's high-octane properties and shifted its niche market from a fuel to an octane enhancer. This market shift benefitted ethanol because it was now competing with additives that were generally higher priced and less ubiquitous than gasoline (see Table 1). At this point, the high value of ethanol's octane was realized by refineries, and they were able to save money by dropping their blendstock for oxygenated blending from 87 to 84 AKI (Smith and Morris 2012).

Despite ethanol's virtues as an octane enhancer, Figure 1 shows that its use stagnated between 1985 and 1990. There were four main reasons for this:

1. Drivers became concerned about ethanol's compatibility with their vehicles. Fuel injectors were introduced in the 1985 model year, and they had numerous problems with getting clogged by impurities (largely olefins and diolefins) in the gasoline. Ethanol was blamed for these malfunctions because it entered many markets at the same time. This resulted in some vehicle owner's manuals warning against ethanol, and the National Conference of Weights and Measures recommended posting "No-Alcohol" signs at gas stations. Twenty-eight states required these postings by 1986 (Herman 1989). 
2. The National Highway Transportation Safety Administration's (NHTSA's) system for testing fuel economy for the Corporate Average Fuel Economy (CAFE) standards penalized ethanol blends because of their lower energy density. To accommodate ethanol and other changes made to gasoline since the first implementation of CAFE, NHTSA altered its fuel economy accounting method. In 1988, it put the "R-factor" in the CAFE calculation to correct for slight differences in heating value of the various certification fuels being used at the time (Sluder et al. 2014; EPA 2014). The R-factor enables NHTSA to account for the lower heating value of E10, but recent research shows that it needs to be adjusted to not penalize fuels containing higher ethanol blends (Sluder and West 2013; Sluder et al. 2014).

3. Ethanol raises the RVP of gasoline. The RVP of gasohol surpassed the 9-psi regulatory limit (in actuality, the practicable limit for E10 is 10 psi due to an EPA waiver allowing a 1-psi increase in vapor pressure for E10 blends) largely because ethanol was splash-blended into existing gasoline instead of match-blended into a low-RVP blendstock (which would have cost more to produce [MathPro Inc. 2011]). In response, Congress granted E10 (which has the highest RVP of any ethanol blends ${ }^{2}$ ) a 1-psi waiver from RVP limitations. This was codified in the 1990 CAA Amendments.

4. Gasoline prices dropped sharply in 1985, making ethanol less competitive. From 1929 to 2016, the lowest three-year gasoline prices were from 1986 to 1988.

\subsection{0-2005: Air Quality Motivates the Use of Oxygenates}

Increasing the oxygen content of gasoline can decrease criteria pollutants such as $\mathrm{CO}$ and volatile organic compounds, and therefore decrease summer concentrations of tropospheric ozone in older-technology engines and vehicles (European Fuel Oxygenates Association 2006). Furthermore, unlike lead, oxygenates allow the use of catalytic converters to further reduce these emissions and $\mathrm{NO}_{\mathrm{x}}$ while retaining octane number.

The CAA Amendments of 1990 were significant steps toward reducing pollution from vehicles (EPA 2017). The amendments received broad support from Congress and were quickly passed into law. These amendments included several unique market-driven mechanisms, such as:

- Facilitating meeting emissions requirements using performance-based standards and banking and trading

- Allowing the use of alternative fuels to meet fleet standard

- Reducing sulfur in coal and natural gas ${ }^{3}$

- Creating a market for biofuels to reduce oil imports

- Promoting energy conservation by utilities. ${ }^{4}$

Industry preferred an oxygenate requirement to reduce vehicle emissions over a composition metric because it could be met by ethanol (35\% oxygen by weight), MTBE $(18 \%)$, or ethyl tert-

\footnotetext{
${ }^{2}$ The increase in vapor pressure for higher-ethanol blends, such as E15 and E20, has not been found to be statistically higher than for E10.

${ }^{3}$ The program's emphasis on clean coal and natural gas was enacted to reduce acid rain.

${ }^{4}$ The market-based approaches of the amendments were designed to allow utilities to meet increasingly stringent emissions standards while simultaneously promoting energy conservation to consumers.
} 
butyl ether (16\%). All three of these options have the additional benefit of being octane enhancers. To facilitate compliance with the 1990 CAA Amendments, the federal excise tax exemption for ethanol was extended for a decade (European Fuel Oxygenates Association 2006).

The Oxygenated Gasoline Program was enacted in November 1992 to reduce wintertime CO emissions in 39 noncompliance areas. This program required that gasoline in these areas contain $2.7 \%$ oxygen by weight. MTBE was the desired oxygenate for many refiners, so its use promptly expanded in 1992 and 1993 (see Figure 1) while ethanol use remained flat.

In 1994, the CAA then required reformulated gasoline in areas out of compliance for ozone pollution. For those areas out of ozone compliance but within $\mathrm{CO}$ compliance, reformulated gasoline had to have a minimum of $2.1 \%$ oxygen by weight. Ethyl tert-butyl ether was one way to add this oxygen to gasoline, but it never got much traction in the U.S. market because it was not cost-competitive with MTBE or ethanol (Traiprasertpong and Svang-Ariyaskul 2012). MTBE use jumped again in 1995 as a result. However, in 1997 the U.S. Geological Survey reported that MTBE was frequently found in urban groundwater supplies (Lapham et al. 1997). Leaked MTBE contaminates drinking water more easily than ethanol or gasoline components because it migrates faster and farther through soil and is more resistant to natural biodegradation (EPA 1998). This prompted state governments and fuel providers to incrementally switch to ethanol (ICIS 2006). Ethanol gradually overtook MTBE as the oxygenate of choice in 2004. Ultimately, the water-quality problems due to MTBE contamination resulted in a nationwide cessation of MTBE blending into gasoline in 2006, well after most locations had already abandoned its use.

Phase I of the reformulated gasoline program began in 1995 and resulted in significant emissions benefits in areas required to use the cleaner-burning gasoline. Phase II further reduced emissions in the worst air-quality areas in the United States. In addition, areas could opt into the reformulated gasoline program voluntarily. While early reformulated gasoline formulations included MTBE, EPA determined that the benefits of the reformulated gasoline program could still be realized without the use of MTBE. This determination by EPA allowed regulation to curtail the use of MTBE in gasoline (EPA 1999). Furthermore, there was an oxygen mandate for RFG areas which was eliminated with the Energy Policy Act of 2005. So as MTBE was being banned from use in many states, EPA allowed RFG to not have a mandatory oxygen content as long as the fuels met the complex model emission limits.

The oxygenate programs left states much autonomy to determine the exact requirements for their gasoline. Given very different local emissions reduction needs to achieve compliance, the number of "boutique" fuels grew rapidly as each location designed fuels specific to its needs. This shows that gasoline distributors can handle a variety of liquid fuels, but in the Biofuels Reduction Act of 2009, Congress limited the emissions-related diversification so that suppliers could more easily distribute their product. Even so, there are now 15 different "boutique" gasoline formulations, not counting mid-grade and premium versions of each one (National Association of Convenience Stores 2016). 


\subsection{5-2016: Energy Security and Climate Protection Motivate the Use of Ethanol}

Recognizing the effects of local switches from MTBE to ethanol, in the Energy Policy Act of 2005, Congress removed the oxygenate requirement for reformulated gasoline and replaced it with the Renewable Fuel Standard (RFS) (EPA 2016a). The RFS requires motor fuels to contain an increasing portion of renewable fuels (primarily met by biofuels ${ }^{5}$ ), which lowers dependence on foreign oil and reduces greenhouse gas (GHG) emissions. At that point, the RFS (and the subsequent RFS2 of 2007) became the primary driving force behind increasing ethanol use. E10 (as opposed to higher blends) was the clear choice for gasoline suppliers to meet the RFS requirements because its full value as an octane number enhancer could be realized in conventional vehicles, and it was compatible with refueling infrastructure. The annual goals of RFS2 (see Figure 2) were set based on gasoline and diesel consumption at the time the legislation was passed. Using the current volume of gasoline consumption at the time meant that full E10 penetration could be achieved with conventional ethanol production technology. An industry hope was that if the RFS2 volumes for ethanol use were sufficiently aggressive compared to the volume of conventional ethanol production, economic barriers for cellulosic ethanol production could be reduced through legislative mandate. Additionally, vehicles capable of using higher-content ethanol fuels (above E10) would be introduced to the market, further increasing ethanol utilization from both conventional and cellulosic sources.

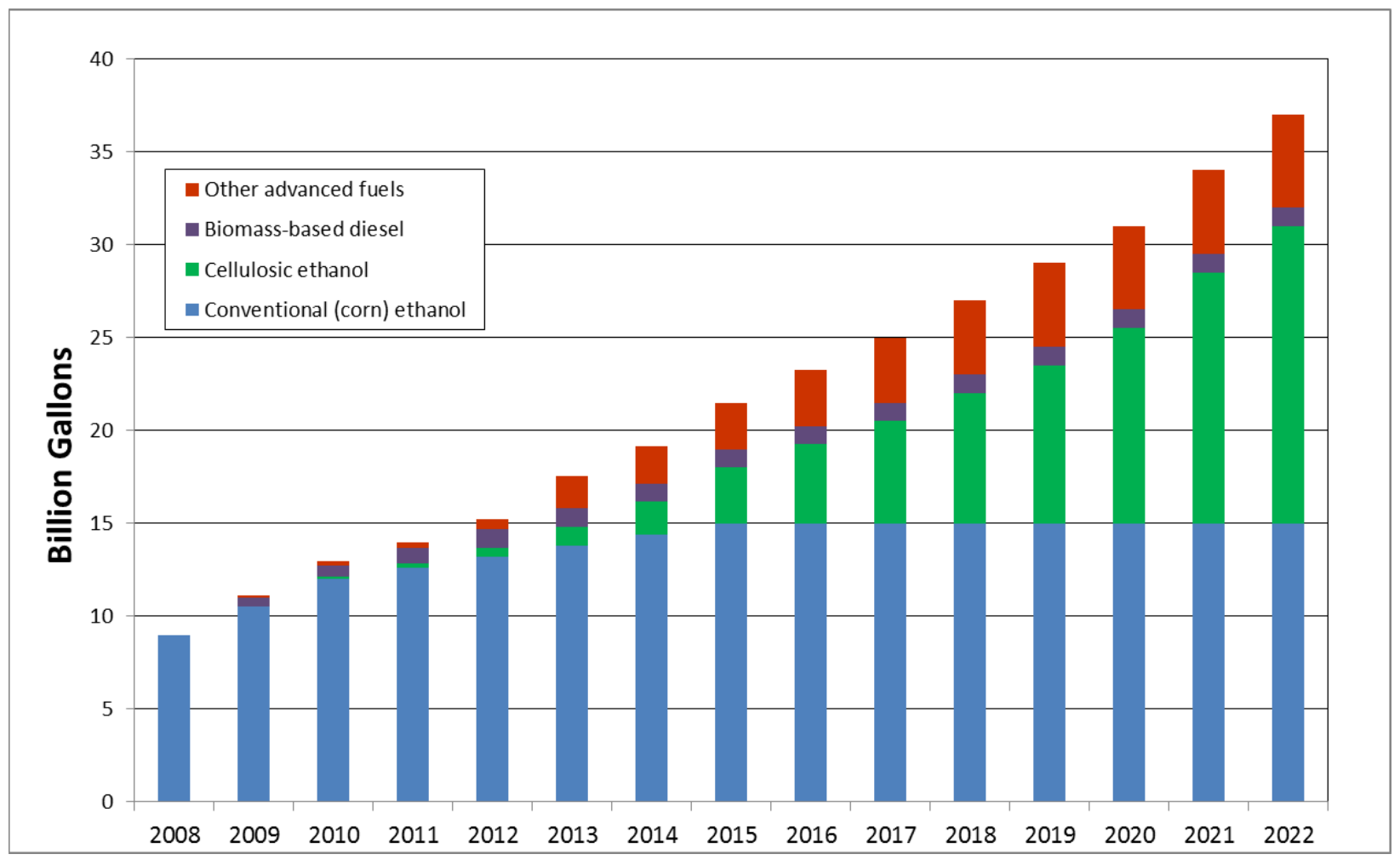

Figure 2. RFS2 legislated biofuel volumes by year

\footnotetext{
${ }^{5}$ Although most of the RFS volumes have been met with biofuels, such as corn ethanol, cellulosic ethanol, biodiesel, and renewable diesel, the program allows for fuels produced through other sources, such as natural gas produced from municipal solid waste.
} 
EPA gained authorization to regulate GHGs as a CAA pollutant in 2007 (Coalition for Responsible Regulations, Inc. et al. v. EPA 2012). This ruling was based upon scientific evidence that GHG emissions have a direct impact on the Earth's climate and therefore on the health and welfare of U.S. citizens (Intergovernmental Panel on Climate Change 1990). EPA applied its new GHG limitations in conjunction with the light-duty vehicle (LDV) CAFE program for the first time in model year 2012. When calculating the GHG emissions, EPA takes the ethanol content of E10 into account, but looks at tailpipe GHG emissions instead of life-cycle GHG emissions. The resulting standard is in close agreement with NHTSA's CAFE regulations for E10 (Federal Register 2012).

Despite the near-complete market penetration of E10 by 2010 (National Research Council 2011), some policies and test procedures are still catching up. Ethanol-free gasoline (E0) remained the certification fuel in Tier 2 emissions standards and CAFE and GHG regulations until 2017. Then the Tier 3 emissions standards displaced Tier 2 and E10 began phasing in as the test fuel. LDV's manufactured by large OEMs began using E10 for emissions tests by model year 2020 and remaining LDVs and HDVs should use E10 as the test fuel by model year 2022. (EPA 2014).

\section{E85 and Flexible-Fuel Vehicles}

\subsection{E85 Regulations}

E85 (sometimes referred to as flex fuel) is a marketing term for a fuel that contains between 51 and 83 volume percent ethanol. E85 has long been seen as a way to increase ethanol use in a way that minimizes transportation and infrastructure costs. This was achievable because, when used in a more concentrated form, the same amount of ethanol could be used closer to its source and transported through fewer terminals and refueling stations. This ethanol market was especially important when MTBE was being used instead of ethanol as the oxygenate in gasoline. Now that the E10 market is saturated, ethanol proponents see E85 fuel as one of the most likely ways to expand ethanol use and therefore reduce emissions and the use of petroleum (Babcock and Pouliot 2013).

E85 use in the United States is still quite limited despite being on the market for over 20 years. Part of the difficulty of expanding the E85 market is that it is not compatible with regular gasoline vehicles or the refueling infrastructure. Therefore, much legislation has been passed to push the market toward adoption of this technology, though with little success. The market push has been three-pronged: aimed at consumers, fuel providers, and vehicle manufacturers. The legislation has attempted to encourage the production and sale of flexible-fuel vehicles (FFVs) while simultaneously developing a market for the fuel (production, infrastructure, and distribution) and a consumer demand for the fuels and vehicles.

\subsection{Flexible-Fuel Vehicles}

E85, unlike E10, cannot be used in regular gasoline vehicles. Therefore, the conundrum of whether to get the fuel or the vehicles on the market first had to be dealt with. For E85, this "chicken-or-egg" dilemma was alleviated by the development of FFVs capable of running on E0, $\mathrm{E} 85$, or anything in between. 
The development of these vehicles was spurred by the 1988 Alternative Motor Fuels Act. This legislation incentivized automakers to produce FFVs through an accounting mechanism in the CAFE standards. This accounting mechanism counted only the gasoline portion of E85 when calculating the fuel economy of an FFV and assumed that E85 was 85\% ethanol by volume. So, when a vehicle that gets 25 miles per gallon ( $\mathrm{mpg}$ ) when operating on gasoline and $19 \mathrm{mpg}$ on E85, it was assumed to get $127 \mathrm{mpg}$ of gasoline (Equation 1). Furthermore, the CAFE regulation for FFVs assumed that FFVs were using E85 50\% of the time. Therefore, the same FFV that achieves $25 \mathrm{mpg}$ on gasoline would count as a vehicle with the efficiency of $42 \mathrm{mpg}$ for CAFE accounting (per Equation 2).

$$
\begin{aligned}
& \text { FFV fuel economy on E85 }=\frac{19 \mathrm{mpg}}{\frac{0.15 \mathrm{gal} \mathrm{gas}}{1 \text { gal E85 }}}=127 \mathrm{mpg} \text { gasoline } \\
& \text { CAFE FFV fuel economy }=\frac{1}{\frac{0.5}{127 \mathrm{mpg}}+\frac{0.5}{25 \mathrm{mpg}}}=42 \mathrm{mpg} \text { gasoline }
\end{aligned}
$$

This CAFE benefit was deemed to be potentially too large, so the overall benefit that FFVs could bestow upon a manufacturer's fleet CAFE average was limited to $1.2 \mathrm{mpg}$. Nevertheless, it was a substantial incentive that prompted the OEMs to develop and market FFVs. Ford first released a Taurus FFV in 1996 (Dever 1996). The incentive was substantial enough to bring 6 million FFVs on the road by 2006 (O'Connor 2007). However, the Energy Independence and Security Act of 2007 scheduled this incentive to be phased out between the years 2015 and 2019 by decreasing the 1.2-mpg cap in 0.2-mpg increments. For model year 2020 and beyond, instead of assuming that FFVs use E85 50\% of the time, weighting of alternative fuel use and gasoline use will be based on demonstrated/projected use in the field (Powell 2015). Despite the incentive being successful in bringing FFVs to market, there were some problems preventing it from creating a robust market for E85.

FFVs get approximately 23\% worse fuel economy when operating on E85 because E85 has a lower energy density than gasoline and FFV engines are not optimized to fully translate the increased octane into improved fuel economy. However, this difference in fuel economy depends on the amount of ethanol in the fuel. Usually the price of E85 is only $11 \%-17 \%$ below that of gasoline (Fuels Institute 2014), meaning that drivers' per-mile fuel costs are more if they are using E85. This discourages FFV owners from using E85.

In addition to the CAFE incentive, FFV purchases have been encouraged through a series of fleet incentives. The incentives with the most impact focus on the federal fleet, because at 600,000 vehicles (U.S. Department of Energy [DOE] 2016), it is the largest fleet in the world. The Energy Policy Act of 1992 required at least 75\% of LDVs acquired in metropolitan areas to be alternative fuel vehicles (AFVs). FFVs were the overwhelming choice of vehicle to meet this requirement because they could simply operate on gasoline. The Energy Policy Act of 2005 then encouraged the use of E85 by mandating that all federal FFVs must use E85 unless waivered due to unavailability of the fuel. The Energy Independence and Security Act of 2007 further encouraged federal FFV purchases by prohibiting the acquisition of vehicles that are not lowGHG-emitting vehicles. FFVs are low-GHG-emitting vehicles by their accounting. 


\subsection{Infrastructure}

There are now 3,860 E85 stations in the United States, which is approximately $2 \%$ of the gasoline stations (U.S. Department of Energy 2020). The geographic distribution of stations varies. For example, there are 416 E85 stations in Minnesota, representing a relatively high concentration of these stations compared to the rest of the United States. Market analysts estimate that a fuel needs to be offered at $20 \%$ of gasoline stations to bring the inconvenience of a new fuel down to an acceptable level (Johnson et al. 2015). Figure 3 shows that the number of E85 stations has been growing since 1992, with two small reductions in 1998 and 2002. This growth was aided by a number of policies.

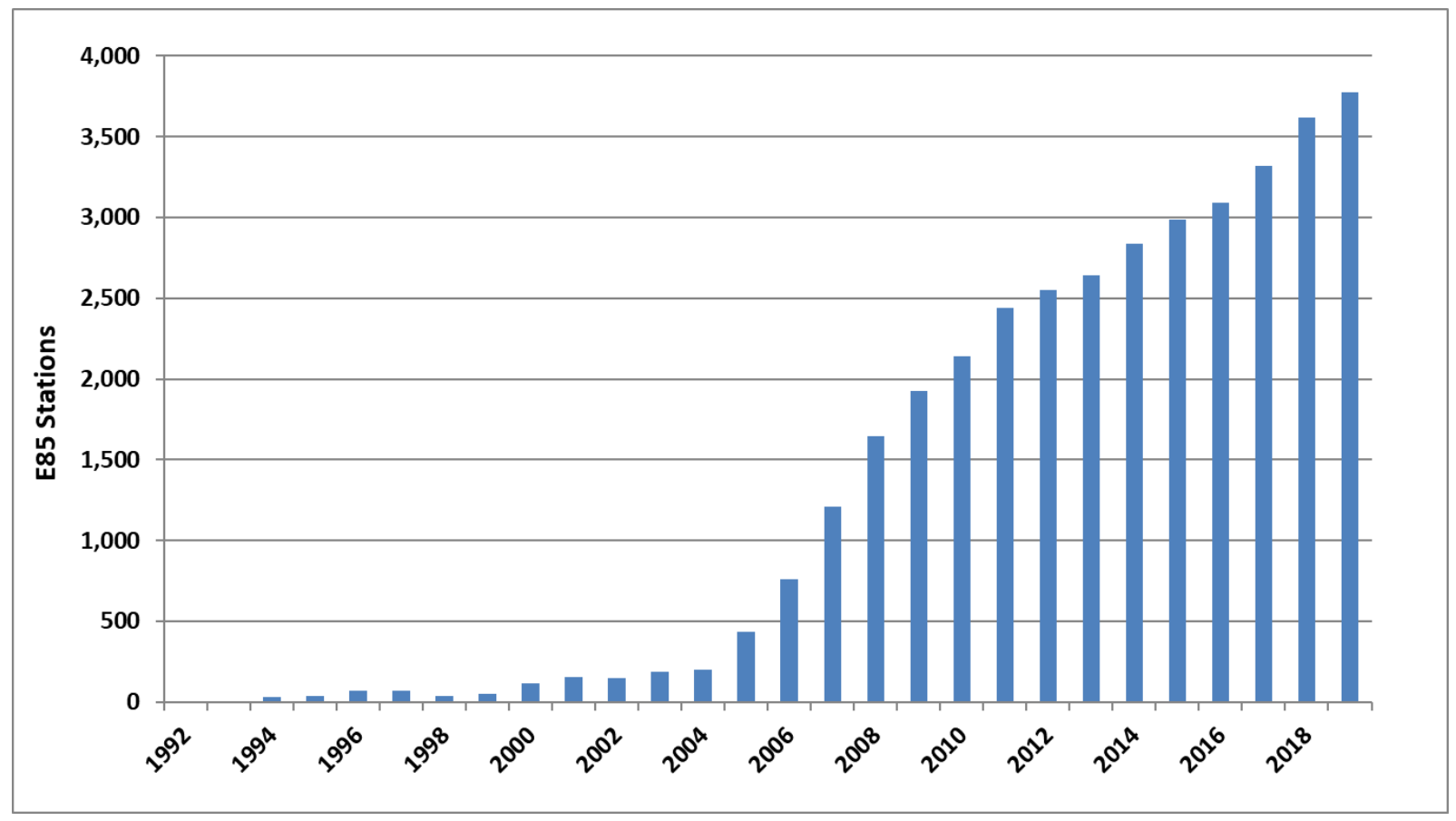

Figure 3. E85 stations in the United States by year

Source: Alternative Fuels Data Center

Figure 3 also shows that the growth in the number of E85 stations greatly accelerated in 2005 . This coincides with the start of the Alternative Fuel Infrastructure Tax Credit, which gave a tax credit of $30 \%$ of the cost of an E85 refueling station, with a cap of $\$ 30,000$ (U.S. Department of Energy 2014a). This tax credit has been extended numerous times, retroactively, either at $30 \%$ or $50 \%$ (with a cap of $\$ 50,000$ ) ever since.

Some steps had to be taken to ensure that refueling equipment could safely dispense E85. It is up to the authority having jurisdiction to permit refueling stations. Many refueling stations were certified before extensive tests were done to know whether the equipment was compatible or not. Finally, in 2007, UL developed certification requirements (UL Subject 87A-E85) for E85 dispensers (UL 2007). Now there are numerous dispensers carrying this certification that authorities having jurisdiction can require for E85 stations (U.S. Department of Energy 2016c). In contrast, there were never any UL listings that included MTBE. 
Because E85 can damage non-FFVs, the Federal Trade Commission requires that E85 dispensers be labeled as such. In the length of time it took to develop this rule and associated label, numerous authorities having jurisdiction and state and local governments had set their own labeling requirements. Furthermore, most retailers reduce misfueling through the use of yellow nozzles for E85 (to match the yellow fuel-tank caps on the FFVs, Figure 4).

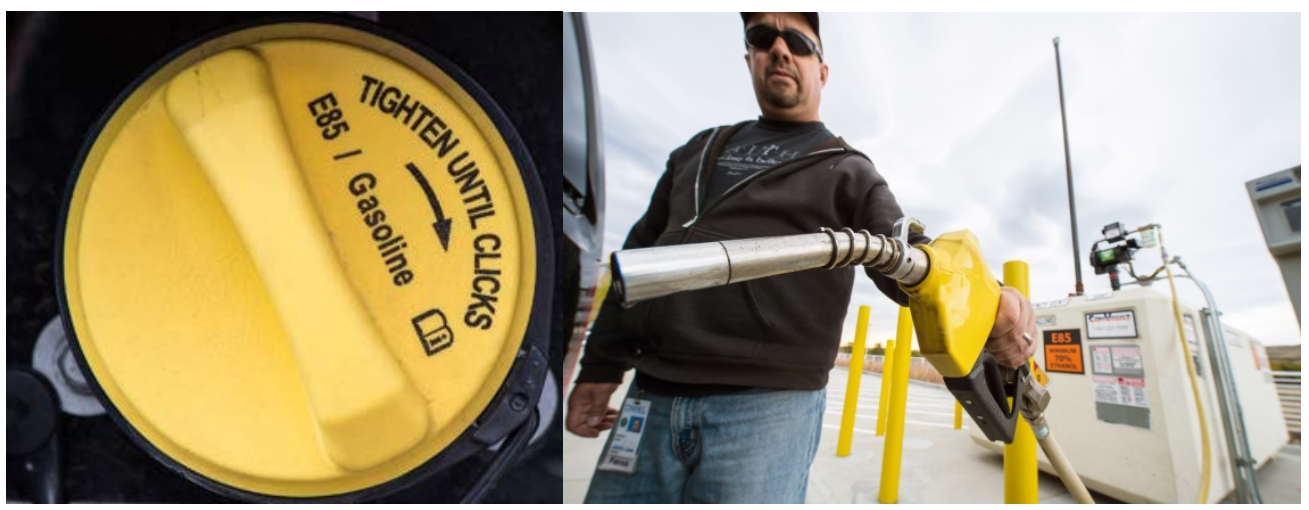

Figure 4. Yellow gas-tank cap of an FFV and matching dispenser nozzle

Source: National Renewable Energy Laboratory 32163 and 32153

Grant programs have also been instrumental in E85 station installations. There have been numerous waves of funding from various sources, but the most significant was the American Recovery and Reinvestment Act of 2009. The American Recovery and Reinvestment Act provided $\$ 300$ million toward alternative fuels and advanced vehicle projects, some of which funded 67 FFV refueling stations (U.S. Department of Energy 2014b). Most federal infrastructure grants require that the grantee provide access to public vehicles. In 2015, the U.S. Department of Agriculture's Farm Service Agency announced the Biofuels Infrastructure Partnership program, which ultimately funded approximately 865 stations with $\$ 82$ million in federal funding and cost-sharing grants for stations to install E15 and E85 equipment (U.S. Department of Agriculture 2015). Industry's Prime the Pump program has also funded stations to extend availability beyond E10.

Fleets were used to aid infrastructure development as well as to put FFVs on the road. The Energy Independence and Security Act of 2007 required that every federal fueling center must install a renewable-fuel pump.

\subsection{Incentives}

Most of the corn and ethanol production incentives discussed in Section 2 also apply to the ethanol portion of E85. This includes the series of tax credits that lasted from 1980 through 2011. However, E85 was different in some fundamental ways that required legislative action to allow it to be sold in the United States.

The first action that needed to be taken was to register E85 as a fuel by DOE under protocol set forth in the 1992 Energy Policy Act (U.S. Congress 1992). It is not "substantially similar" to gasoline; therefore, it had to be registered directly. This recognition was confirmed for E85 when it was defined as a "clean alternative fuel" under the CAA Amendments of 1990. 


\section{E15}

\subsection{Regulations to Allow E15}

E15 is a blend of $10.5 \%$ to $15 \%$ ethanol with gasoline (EPA 2015). As with E85, E15 is seen as a way to surpass the so-called ethanol blend wall. The CAA does not allow new fuels or fuel additives that are not "substantially similar" to the existing fuels and fuel additives that were used to certify vehicles and engines for emission standards. A waiver can be granted for a new fuel or fuel additive if data are provided that show that there is no negative impact to vehicles and engines in meeting emission standards. Growth Energy, an ethanol industry group, and 54 ethanol plant owners submitted a waiver request for E15 in March 2009 (EPA 2012). The DOE's Oak Ridge National Laboratory and National Renewable Energy Laboratory, along with the ethanol industry, developed data that demonstrated no adverse effect on vehicles, engines, or human health (McCormick et al. 2013). In March 2009, EPA issued a partial waiver approving E15 for model year 2007 and newer LDVs, and upon review of additional data, extended the waiver to model year 2001 and newer LDVs (Federal Register 2011). Due to a lack of data in the request, the waiver prohibits the use of E15 in heavy-duty gasoline vehicles, motorcycles, and non-road engines and equipment, including boats, snowmobiles, lawnmowers, leaf blowers, and similar small engines.

\subsection{E15 Regulations}

It is possible that state and local authorities may have additional requirements on fuels beyond those imposed at the federal level. EPA's Office of Transportation and Air Quality developed requirements for E15 sales to reduce the risk of misfueling because the fuel is only approved for use in LDVs and trucks model year 2001 and newer. These regulations do not apply to E10 gasoline, diesel, or other renewable fuels. Stations selling E15 must adhere to the following requirements:

1. An EPA-approved E15 label must be affixed to the dispenser

2. An EPA-approved Misfueling Mitigation Plan (available for free from the Renewable Fuels Association) must be adopted (EPA 2012)

3. Product transfer documents must accompany all deliveries of fuel for E15 use

4. The retail station must participate in the fuel quality survey

5. Ethanol in E15 must meet ASTM D4806. As of 2019, E15 now qualifies for the same RVP 1 pound waiver as E10 (EPA 2019).

6. Stations must use EPA-approved dispenser and hose configurations. Options include:

a. A dedicated E15 hose

b. A shared E0/E10/E15 hose, which requires a purchase of four gallons minimum ("four gallons minimum" label must be displayed)

c. A dedicated dispenser selling E10 or less.

In addition to the above regulations, EPA's Office of Underground Storage Tanks regulates underground storage tanks per Code of Federal Regulations Title 40, Part 1, Subchapter 1, Parts 280-282. This code was updated in July 2015 with Code of Federal Regulations Title 40, Part 1, 
Subchapter 1, Part 280.32, adding compatibility requirements for ethanol blends above E10. The following equipment must be compatible with the fuel stored: tank, piping, containment sumps, pumping equipment, release detection equipment, spill equipment, and overfill equipment. Stations storing blends above E10 must:

1. Notify its implementing agency (usually a state office) 30 days prior to storing an E10+ blend

2. Use compatible equipment and demonstrate compatibility through one of three methods:

a. Certification/listing of equipment by an independent testing laboratory

b. Equipment or component manufacturer approval, in writing, affirming compatibility with a specific range of biofuel blend

c. Use of another method determined by the implementing agency to be no less protective of human health and the environment

3. Maintain records demonstrating compatibility for the entire time a blend greater than E10 is stored.

The Petroleum Equipment Institute and Steel Tank Institute maintain websites with manufacturer letters affirming compatibility with a specific range of biofuel blend. Use of manufacturer letters by station owners satisfies the federal code requirement (Petroleum Equipment Institute 2016; Steel Tank Institute 2012).

\subsection{E15 Incentives}

The sole federal incentive for E15 was the 2015 U.S. Department of Agriculture's Biofuel Infrastructure Partnership, which sought to extend the availability of ethanol blends above E10 (U.S. Department of Agriculture 2015). The Biofuel Infrastructure Partnership was a competitive grant program for states wishing to install ethanol infrastructure at retail stations. The program provided $\$ 82$ million in cost-sharing funds, while states (including state-private partnerships) provided an additional matching cost-share. Twenty-one states were selected to receive funding for E15 and/or E85 infrastructure. This program funded approximately 865 stations, including more than 3,500 dispensing systems and 180 tank systems. The ethanol industry provides funding for E15 infrastructure through programs such as Prime the Pump (Retka Schill 2014).

\subsection{Conclusion}

Ethanol is now the most-consumed non-petroleum transportation fuel in the United States for a number of reasons. First, its high octane improves engine performance. Second, it is being introduced into three separate fuels-E10, E15, and E85 - with different niches and markets. Finally, ethanol helps the United States achieve numerous policy goals related to air quality, energy security, climate change, and engine performance. Throughout the years, these goals have rotated through the role of being the primary motivating factor for the pursuit of ethanol. But together, they provided consistent long-term support that enabled ethanol to be a permanent and important component of our nation's fuel supply. 


\section{References}

Babcock, Bruce A. and Sebastien Pouliot. 2013. "Price It and They Will Buy: How E85 Can Break the Blend Wall." CARD Policy Briefs, Paper 13. http://lib.dr.iastate.edu/card_policybriefs/13.

Bechtold, Richard L. 1987. Compendium of Significant Events in the Recent Development of Alcohol Fuels in the United States. Oak Ridge, TN: Oak Ridge National Laboratory. Report ORNL/Sub/85-22007/1.

Bechtold, Richard L., Marc B. Goodman, and Thomas. A. Timbario. 2007. Use of Methanol as a Transportation Fuel. Report prepared for the Methanol Institute.

Coalition for Responsible Regulations, Inc. et al. v. Environmental Protection Agency. 2012. United States Court of Appeals. No. 09-1322.

Colucci, Joe M. 2013. "Where Will The Octane Come From?” Presentation at the SAE 2013 International High Octane Fuels Symposium, Washington, D.C., January 29, 2013.

Crude Oil Windfall Profits Tax of 1980, Pub. L. No. 96-223, 1980.

Dever, Paul. 1996. "Alternative Fuel Ford Taurus.” 1996 North American International Auto Show Press Release, January 1996. Accessed March 15, 2016. http://www.theautochannel.com/news/date/19960123/news00023.html.

Energy Tax Act, Pub. L. No 95-618, 1978.

European Fuel Oxygenates Association. 2006. "MTBE Resource Guide." https://www.sustainablefuels.eu/assets/uploads/2018/08/20100715142838mtbe resource_guide_-2006_revision.pdf

Federal Register. 1979. "Fuels and Fuel Additives: Gasohol; Marketability." Federal Register, April 6, 1979. Accessed March 22, 2016.

Federal Register. 2011. "Environmental Protection Agency [EPA-HQ-OAR-2009-0211; FRL9258-6], Partial Grant of Clean Air Act Waiver Application Submitted by Growth Energy to Increase the Allowable Ethanol Content of Gasoline to 15 Percent; Decision of the Administrator." Federal Register, Vol. 76, No. 17, January 26, 2011. Accessed August 8, 2016. https://www.gpo.gov/fdsys/pkg/FR-2011-01-26/pdf/2011-1646.pdf.

Federal Register. 2012. "2017 and Later Model Year Light-Duty Vehicle Greenhouse Gas Emissions and Corporate Average Fuel Economy Standards." Federal Register, November 15, 2012. Accessed March 8, 2016.

Fuels Institute. 2014. "E85: A Market Performance Analysis and Forecast." Accessed March 16, 2016. https://www.fuelsinstitute.org/Research/Reports/E85-A-Market-Performance-Analysisand-Forecast 
Ghosh, Prasenjeet, K.J. Hickey, and S.B. Jaffe. 2006. "Development of a Detailed Gasoline Composition-Based Octane Model.” Ind. Eng. Chem. Res. 45 (1): 337-345.

DOI:10.1021/ie050811h.

Herman, Marilyn J. 1989. Survey of Federal and State Oxygenated Fuel Regulations: Motor Fuel Laws and Tax Incentives. Washington, D.C.: Herman \& Associates.

ICIS. 2006. "Timeline: A Very Short History of MTBE in the US." Accessed March 8, 2016. http://www.icis.com/resources/news/2006/07/05/1070674/timeline-a-very-short-history-of-mtbein-the-us/.

Intergovernmental Panel on Climate Change. 1990. Climate Change: The IPCC Scientific Assessment. Cambridge, MA: Cambridge University Press.

Lapham, W.W, Neitzert, K.M., Moran, M.J., and Zogorski, J.S., 1997. USGS compiles data set for national assessment of VOCs in ground water: Ground Water Monitoring and Remediation, v. 17 , no. 4 p. 147-57.

Johnson, Caley, Emily Newes, Aaron Brooker, Robert McCormick, Steve Peterson, Paul Leiby, Rocio Uria-Martinez, Gbadebo Oladosu, and Maxwell L. Brown. 2015. High-Octane Mid-Level Ethanol Blend Market Assessment. Golden, CO: National Renewable Energy Laboratory. Report No. NREL/TP-5400-63698.

MathPro Inc. 2011. "Refining Economics of a National Low Sulfur, Low RVP Gasoline Standard." Accessed March 8, 2016.

http://www.theicct.org/sites/default/files/publications/ICCT04_Tier3_Report_Final_v4_All.pdf.

McCormick, Robert, Janet Yanowitz, Matthew Ratcliff, and Bradley Zigler. 2013. Review and Evaluation of Studies on the Use of E15 in Light-Duty Vehicles (Technical Report). Golden, CO: National Renewable Energy Laboratory. Prepared for the Renewable Fuels Association. http://www.ethanolrfa.org/wp-content/uploads/2015/09/RFA-NREL-Review-and-Evaluation-ofE15-Studies.pdf.

Morris, David J. 1992. Ethanol Policy and Development: 1978-1992. Minneapolis, MN: Institute for Local Self Reliance.

National Association of Convenience Stores. 2016. "The U.S. Petroleum Industry: Statistics, Definitions." Accessed March 8, 2016.

http://www.nacsonline.com/yourbusiness/fuelsreports/gasprices_2013/pages/statistics-anddefinitions.aspx.

National Research Council. 1991. Rethinking the Ozone Problem in Urban and Regional Air Pollution. Washington, D.C.: National Academies Press.

National Research Council, Committee on Economic and Environmental Impacts of Increasing Biofuels Production. 2011. Renewable Fuel Standard: Potential Economic and Environmental Effects of US Biofuel Policy. Washington, D.C.: National Academies Press. 
O'Connor, J.K. 2007. Historical Perspective of Clean Cities and Alternative Fuels Data Center Trends. Golden, CO: National Renewable Energy Laboratory. NREL/TP-540-41069. www.nrel.gov/docs/fy07osti/41069.pdf.

Peeples, J.E. 1991. "The Clean Air Act: A Brave New World for Fuel Reformulation.” Fuel Reformulation 1: 27-31.

Petroleum Equipment Institute. 2016. "UST Component Compatibility Library.” Accessed March 8, 2016. http://www.pei.org/ust-component-compatibility-library.

Powell, Gregory. 2015. "Alternative Fuels in CAFE Rulemaking." Presented at SAE Government and Industry Meeting, Washington, D.C., January 21, 2015.

Retka Schill, Susanne. 2014. "Prime the Pump Seeks to Expand E15 Infrastructure." Ethanol Producer Magazine, December 10, 2014. Accessed March 22, 2016.

http://www.ethanolproducer.com/articles/11734/prime-the-pump-seeks-to-expand-e15infrastructure.

Round, George. 1973. George Round Oral Histories, Agricultural Communications Records, RG-08-16-05. Archives \& Special Collections, University of Nebraska-Lincoln Libraries. https://archives.nebraska.edu/repositories/8/resources/1413 Accessed July 13, 2020.

Sluder, C.S. and B.H. West. 2013. Preliminary Examination of Ethanol Fuel Effects on EPA's RFactor for Vehicle Fuel Economy (Technical Report). Oak Ridge, TN: Oak Ridge National Laboratory. ORNL/TM-2013/198.

Sluder, C.S., B. West, A. Butler, A. Mitcham, and W.J. Ruona. 2014. "Determination of the R Factor for Fuel Economy Calculations Using Ethanol-Blended Fuels over Two Test Cycles." SAE Int. J. Fuels Lubr. 7 (2): 551-562. doi:10.4271/2014-01-1572.

Smith, William Ed, IV and William E. Morris. 2012. "RVP Blending Values Listed for Light HCs.” Oil \& Gas Journal 110 (10):100-101. Accessed March 8, 2016.

Splitter, D., A. Pawlowski, and R. Wagner. 2016. "A Historical Analysis of the Co-evolution of Gasoline Octane Number and Spark-Ignition Engines." Frontiers in Mechanical Engineering 1: 16. doi:10.3389/fmech.2015.00016.

Steel Tank Institute. 2012. "Steel and Alternative Fuels." Accessed March 8, 2016. http://www.steeltank.com/FabricatedSteelProducts/ShopFabricatedTanks/SteelandAlternativeFu els/tabid/465/Default.aspx.

Traiprasertpong, P. and A. Svang-Ariyaskul. 2012. "Process Simulation of Ethyl Tert-Butyl Ether (ETBE) Production from Naphtha Cracking Wastes." World Academy of Science, Engineering and Technology 64: 1033-1038.

Underwriters Laboratories. 2007. "Underwriters Laboratories Announces Development of Certification Requirements for E85 Dispensers." October 16, 2007. Accessed March 17, 2016. http://www.ul.com/wp-content/uploads/2014/04/e85certificationrequirements.pdf. 
U.S. Congress. 1992. Energy Policy Act. H.R. 776. Accessed July 30, 2020:

https://afdc.energy.gov/files/pdfs/2527.pdf:

U.S. Department of Agriculture. 2015. "USDA Announces \$210 Million to be Invested in Renewable Energy Infrastructure through the Biofuel Infrastructure Partnership," News Release No. 0300.15. Accessed November 30, 2015. https://www.usda.gov/wps/portal/usda/usdahome? contentid=2015/10/0300.xml\&navid=NEWS $\underline{\text { RELEASE\&navtype }=\text { RT\&parentnav }=\text { LATEST RELEASES\&edeployment action }=\text { retrievecont }}$ ent.

U.S. Department of Energy. 2014a. "Alternative Fuel Infrastructure Tax Credit." Accessed March 17, 2016. http://www.afdc.energy.gov/laws/10513.

U.S. Department of Energy. 2014b. "American Recovery and Reinvestment Act of 2009." Accessed March 17, 2016. http://www.afdc.energy.gov/laws/arra.html.

U.S. Department of Energy. 2020. "Alternative Fueling Stations Counts by State." Accessed March 17, 2016. http://www.afdc.energy.gov/fuels/stations_counts.html.

U.S. Department of Energy. 2016. "Federal Automotive Statistical Tool Data Collection." Accessed March 17, 2016. https://federalfleets.energy.gov/federal_requirements/reporting/fast.

U.S. Department of Energy. 2016c. "Handbook for Handling, Storing, and Dispensing E85 and Other Ethanol-Gasoline Blends." Golden, CO: DOE/GO-10216-4854.

U.S. Energy Information Administration. 2016. "Almost all U.S. gasoline is blended with 10\% ethanol." Accessed July 13, 2020. https://www.eia.gov/todayinenergy/detail.php?id=26092

U.S. Environmental Protection Agency. 1998. "MTBE Fact Sheet \#2: Remediation of MTBE Contaminated Soil and Groundwater.” Accessed March 8, 2016. https://archive.epa.gov/oust/mtbe-a/web/pdf/mtbefs2.pdf.

U.S. Environmental Protection Agency. 1999. "Phase II Reformulated Gasoline: The Next Major Step Toward Cleaner Air." EPA420-F-99-042. Accessed April 6, 2017. https://nepis.epa.gov/Exe/ZyPDF.cgi/00000FG5.PDF?Dockey=00000FG5.PDF.

U.S. Environmental Protection Agency. 2012. "Model E15 Misfueling Mitigation Plan." Renewable Fuels Association. March 2, 2012. Accessed January 5, 2015. https://www.epa.gov/fuels-registration-reporting-and-compliance-help/e15-fuelregistration\#mmp.

U.S. Environmental Protection Agency. 2014. "Control of Air Pollution from Motor Vehicles: Tier 3 Motor Vehicle Emission and Fuel Standards Rules and Regulations." Office of the Federal Register. Accessed March 8, 2016. https://www.gpo.gov/fdsys/pkg/FR-2014-04-28/pdf/201406954.pdf.

U.S. Environmental Protection Agency. 2015. "Ethanol Waivers (E15 and E10)." Accessed July 30, 2020. https://www.epa.gov/gasoline-standards/ethanol-waivers-e15-and-e10. 
U.S. Environmental Protection Agency. 2016a. "Renewable Fuel Standard Program." Accessed March 8, 2016. https://www.epa.gov/renewable-fuel-standard-program.

U.S. Environmental Protection Agency. 2017. "1990 Clean Air Act Amendment Summary." Accessed April 6, 2017. https://www.epa.gov/clean-air-act-overview/1990-clean-air-actamendment-summary.

U.S. Environmental Protection Agency. 2019. "Compliance Overview for the E15 RVP and RIN Market Reform Final Rule.” Accessed July 30, 2020. www.epa.gov/renewable-fuel-standardprogram/compliance-overview-e15-rvp-and-rin-market-reform-final-rule 